\title{
INTEGRATED URBAN AIR QUALITY CONTROL AND MANAGEMENT
}

\author{
Linas Kliučininkas \\ Kaunas University of Technology, Lithuania
}

\section{Introduction}

This paper will present experiences gained from the municipal project Agenda - 21 Kaunas financed by Phare Cross Border Co-operation Project Facility. The Environmental Quality Group consisting of experts in the fields of environmental monitoring, energy production, urban planning and health were representing broad spectrum of municipal management activitiesq1).

Improvement of urban air quality control and related "bottle-necks" in the city planning and management was set as the top priority for the Group.

It was distinguished that traffic and energy production/supply/utilization sectors are major contributors to the ambient air quality in Kaunas city. As a result, the Group has developed recommendations for further development of these sectors.

Principal links between areas effecting urban air quality are presented in the Fig.1.

\section{Expenses for health care}

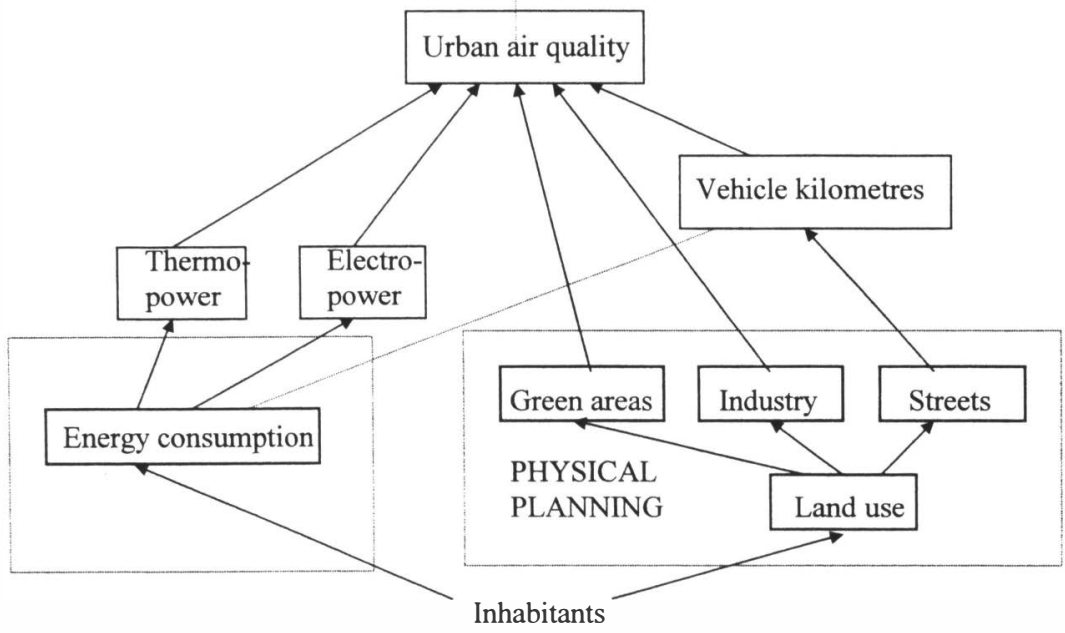


Figurel

According to the EU-regulations and existing practices for ambient air quality control, continuous hourly averaged measurements of $\mathrm{SO}_{2}, \mathrm{CO}, \mathrm{NO}_{\mathrm{x}}, \mathrm{O}_{3}$, aromatic hydrocarbons and particulate matter should be accomplished in the urban environment. This could be ensured only by the automated system, which requires comprehensive data sets used for a more detailed analysis of noxious substances dispersion and of chemical processes in relation to the meteorological parameters and traffic counting, they can also be used for testing air quality models (2).

Sulphur dioxide is a primary pollutant that is emitted mainly by house heating installations and industrial plants and only in small amounts by road traffic (from diesel engines). The main source is the combustion of S-containing fuels, oil and coke. Its mean levels are expected to be higher in the cold season, particularly when low temperatures are observed.

Carbon monoxide, the most stable pollutant associated with traffic, will not be transformed much within the urban area. A decrease in $\mathrm{CO}$ concentration will only be a result of dispersion. For pollutants emitted from the same source a strong correlation is expected, if no reactions occur.

Nitrogen oxides $\left(\mathrm{NO}, \mathrm{NO}_{2}\right)$ are emitted from petrol cars, from diesel cars and from combustion of fossil fuel. $\mathrm{NO}$ will be transformed to $\mathrm{NO}_{2}$, but the total concentration of $\mathrm{NO}+\mathrm{NO}_{2}$ will remain constant, apart from the losses due to dispersion. This consideration explains good correlation observed between $\mathrm{CO}$ and $\mathrm{NOx}$.

Ozone is a secondary pollutant formed by photochemical processes from VOC and NOx in the urban atmosphere or transported from other locations outside the urban area. Its highest levels are reached in the warm season, in the presence of anticyclonic conditions. It follows a diumal cycle, with maxima in early afternoon; at a lower concentrations PAN (peroxi-acetyl-nitrate) follows a similar diumal cycle. Some ozone is consumed in the street by reaction with NO, which means that a lower concentrations should be expected in the street than above the roof tops. During the cold season and under a cloudy sky, the photochemical activity is strongly reduced.

Most of NOx emitted from vehicles is emitted as NO; only $5-10 \%$ is emitted directly as $\mathrm{NO}_{2}$, possibly formed in the exhaust system. The only important fast chemical transformation of $\mathrm{NO}$ to $\mathrm{NO}_{2}$ which can take place in a street is the oxidation by $\mathrm{O}_{3}$ :

$$
\mathrm{NO}+\mathrm{O}_{3} \rightarrow \mathrm{NO}_{2}+\mathrm{O}_{2}
$$

This means that the concentrations of $\mathrm{NO}_{2}$ in a street often are limited by the availability of ozone which is supplied from the surroundings.

Aromatic hydrocarbons $\left(\mathrm{C}_{6} \mathrm{H}_{6}, \mathrm{C}_{7} \mathrm{H}_{8}, \mathrm{C}_{8} \mathrm{H}_{10}\right)$ are primary pollutants emitted by the road traffic. Benzene and toluene, both of which are emitted from the road traffic, will be transformed by chemical reactions when $\mathrm{OH}$-radicals are formed by photochemical processes involving $\mathrm{NO}, \mathrm{NO}_{2}$, ozone and hydrocarbons in presence of sunlight. These conditions will occur in particular in the warm summer days. Benzene is more stable than toluene, which means that the ratio between benzene and toluene will increase as a function of age of the polluted air masses and photochemical activity. 


\section{Energy sector}

Kaunas energy sector yearly produces $1900 \mathrm{MW}$ of thermal power and $180 \mathrm{MW}$ of electric power. These sources produce about $97,4 \%$ of heat and about $40 \%$ of electricity needed for Kaunas. During the last ten years the production of heat was reduced about two times, mostly because of reduced industry and domestic hot water demand.

Figure 2

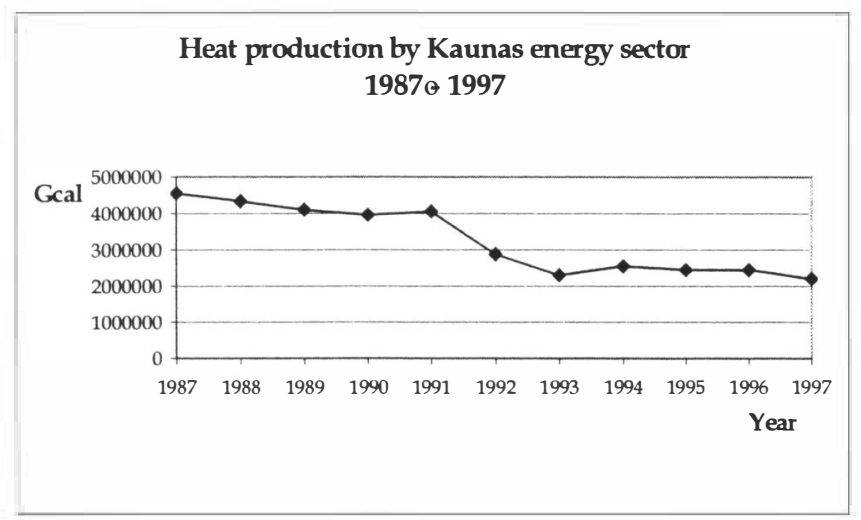

At present natural gas makes up about $68 \%$ and heavy fuel oil (HFO) about $32 \%$ of the total city heat production balance. During the last years when the HFO became more expensive, the amount of used gas has increased.

The toxic waste that comes from the energy sector mainly consists of $\mathrm{SO}_{2}(54 \%)$ and NOx (28\%). The amount of other pollutants - CO, carbon hydroxides, particulate matter, is much more lower. Amounts of $\mathrm{SO}_{2}$ and $\mathrm{CO}$ have decreased 2.5-3 times in comparison with the year 1994 .

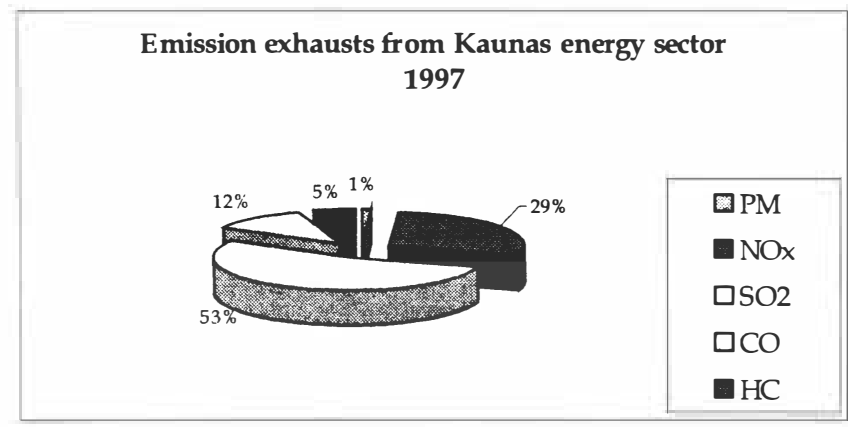

Figure 3 
Flue gases cleaning from the sulphur compounds is very expensive. Oil, used in Kaunas energy production system, contains $2.6 \%$ of sulphur and during the burning process concentration of emitted sulphur compounds 1,64 times exceed maximal threshold limits. To receive $1 \mathrm{MJ}$ of burning heat fuel price is $2-2,5$ times lower then using fuel with lower content of sulphur. The most realistic method to reduce the $\mathrm{SO}_{2}$ concentrations in flue gases is to burn heavy fuel and gases at the same time. Optimal burning mixture will require $1 \mathrm{~kg}$ of heavy fuel $(2.5 \%$ of $\mathrm{S})$ and $0,68 \mathrm{~m}^{3}$ of natural gas.

However, combined burning could not be performed in many boilers due to technical problems.

Use of secondary-rate (lower temperature) heat power, that can be produced by the boiler houses and from the various technological processes at the enterprises, will allow to sell energy with the lower price and with the lower fuel amount burnt in the city, at the same time will reduce emission exhausts.

Based on existing environmental legislation of Lithuania number of indicators regulate level of threshold emissions ( $\mathrm{g} / \mathrm{s}$, t/year) and concentrations of toxic materials $\left(\mathrm{mg} / \mathrm{m}^{3}\right)$, however these indicator do not reflect efficiency of burning and do not stimulate improvements. Much more informative will be indicators relating amount of toxic compounds with the energy produced, for example $\mathrm{kgNOx} / \mathrm{MJ}$ or $\mathrm{kgSO}_{2} / \mathrm{MWh}$. Such indicators are universal and allow evaluation of heat production and supply systems, also enable estimation negative influence on environment.

\section{Urban Planning}

The group has considered that urban planning is one of the important issues having direct effect on air quality management in the city. Formation of new urban structures has direct effiect on the intensity of the traffic (vehicle kilometres travelled), which at he moment comprise $85 \%$ of the total air pollution in Kaunas. Growth dynamics of number of vehicles per 1000 inhabitants for Kaunas, Vilnius and Lithuania are presented in the Figure 4.

Figure 4

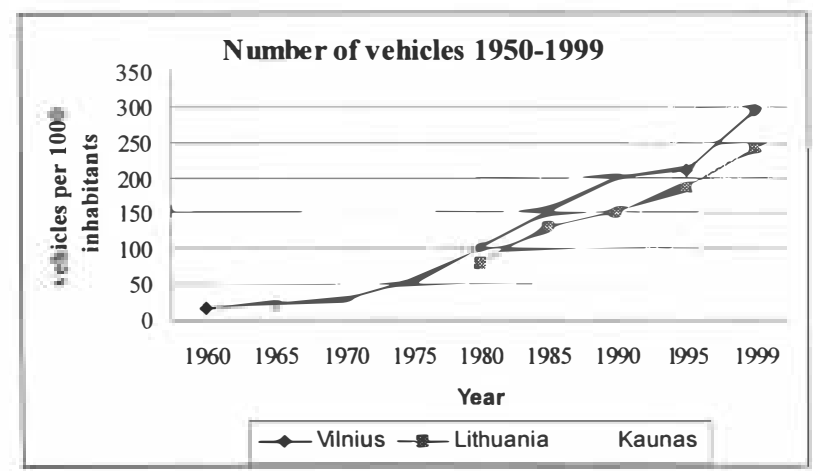

To create an optimal functional structure in the downtown of Kaunas the new bridge with the intensive transit transport corridor (Griunvaldo and Čiurlionio str.) should be developed. One of the preconditions for air quality improvement in the central part of the city is partial 
distribution of it's functions to the peripheral districts of Kaunas (Vilijampolè, Žemoji Freda and others).

Kaunas is situated on the conjunction of two major rivers which form steep slopes with valleys. These "micro-climatic" areas cumulate pollutants and form conditions unfavourable for living. Rare industries situated in the valleys should be taken out to remote parts of the city. At the same time valleys, as the natural heritage of the city, should create unified natural framework.

In the long run the main traffic rout (Savanoriu ave.) connecting Kaunas and Vilnius should be replaced by the rout in the eastern part of the city (Pranones ave., Baršausko str., Bakanausko str.). This will also decrease pendulum movement of the transport from the living districts to the old city and downtown.

\section{Discussion}

The main tasks of urban air quality management : to verify emission inventories and models, to provide information for public, identify qualitative and quantitative characteristics of air pollution sources in order to involve decision makers in effective air pollution management activities.

As a recommendation for the integrated city management the Environmental Quality Group has suggested introduction of urban environment indicators. The set of indicators has been selected according to the following criteria: A. Indicators of Urban Patterns, B. Indicators of Urban Flows, C . Indicators of Urban Environmental Quality (3). Indicators related to the urban air quality monitoring and management are presented in the table. 


\begin{tabular}{|c|c|c|}
\hline Attributes & Description & Indicators \\
\hline \multicolumn{3}{|c|}{ A. Indicators of Urban Patterns } \\
\hline Urban population & $\begin{array}{l}\text { a. Population } \\
\text { b. Population density }\end{array}$ & $\begin{array}{l}\text { Number of inhabitants } \\
\text { Population per } \mathrm{km}^{2}\end{array}$ \\
\hline \multirow[t]{2}{*}{ Urban land cover } & a. Total built-up area & $\begin{array}{l}\text { Area in } \mathrm{km}^{2} \\
\text { By land use }\end{array}$ \\
\hline & $\begin{array}{l}\text { b. Open areas } \\
\text { c. Transportation network }\end{array}$ & $\begin{array}{l}\% \text { green areas } \\
\text { motorway length in } \mathrm{km} \\
\text { railway length in } \mathrm{km} \\
\% \text { of total urban areas }\end{array}$ \\
\hline \multirow[t]{3}{*}{ Urban mobility } & a. Modal split & $\begin{array}{l}\text { Number and average length } \\
\text { of trips in km per inhabitant } \\
\text { per mode of transportation } \\
\text { per day }\end{array}$ \\
\hline & b. Traffic volumes & $\begin{array}{l}\text { Total and inflow/outflow in } \\
\text { vehicle-kms }\end{array}$ \\
\hline & & $\begin{array}{l}\text { Number of vehicles on the } \\
\text { main routs }\end{array}$ \\
\hline \multicolumn{3}{|c|}{ B. Indicators of urban flows } \\
\hline \multirow[t]{2}{*}{ Energy } & a. Energy production & $\begin{array}{l}\text { Energy production in GWh } \\
\text { per year }\end{array}$ \\
\hline & $\begin{array}{l}\text { b. Energy consumption } \\
\text { c. Pollutants per produced } \\
\text { energy unit }\end{array}$ & $\begin{array}{l}\text { Energy use in GWh per year } \\
\mathrm{kgNOx} / \mathrm{MJ} \text { or } \mathrm{kgSO} 2 / \mathrm{MWh}\end{array}$ \\
\hline
\end{tabular}

Table

Table continued

\section{Indicators of urban environmental quality}

\begin{tabular}{ll}
\hline Quality of air & Annual mean concentrations: \\
& $\mathrm{SO}_{2}, \mathrm{NO}_{\mathbf{x}}, \mathrm{CO}, \mathrm{O}_{3}, \mathrm{PM}$, \\
& $\mathrm{C}_{6} \mathrm{H}_{6}, \mathrm{C}_{7} \mathrm{H}_{8}, \mathrm{C}_{8} \mathrm{H}_{10}$ \\
& Exceedances of $\mathrm{SO}_{2}, \mathrm{NO}_{\mathbf{x}}$, \\
& $\mathrm{CO}, \mathrm{O}_{3}, \mathrm{PM}, \mathrm{C}_{6} \mathrm{H}_{6}, \mathrm{C}_{7} \mathrm{H}_{8}$, \\
& $\mathrm{C}_{8} \mathrm{H}_{10}$ \\
\hline
\end{tabular}

The use of indicators does not mean that it is possible at this stage to identify any causal relationships between attributes, however it should be seen a way of categorizing major environmental problems. Nevertheless, as time series data are collected and analysed for these indicators, patterns and relationships may emerge the highlight connections and interactions among indicators. This is the process of trial and error of testing until a set of indicators is available.

As the next step of sustainable city planning and management, development of Driving force-State-Response (DSR) framework of indicators is foreseen. 


\section{References}

1. Kliučininkas L., Lukošius S., Buinevičius K., Gylys J. (1999). Integrated Kaunas City Environmental Management. Report from Agenda- 21 Kaunas, Phare Cross Border Co-operation Project Facility. Kaunas Municipality, Kaunas, p. 56.

2. Criteria for EUROAIRNET (1999). The EEA Air Quality Monitoring and Information Network. EuropeanEnvironmental Agency, Copenhagen, p.256.

3. Europe's Environment: The Dobris Assessment (1995). European Environment Agency, Copenhagen, P.261-289. 